\title{
Religious Leader's Knowledge, Stigma, and Support for People Living with HIV and AIDS (PLHIV) in Kupang
}

\author{
Imelda F.E. Manurung ${ }^{1}$, Chatarina U. Wahyuni ${ }^{2}$, Ari Probandari ${ }^{3}$ \\ ${ }^{1}$ Faculty of Public Health, Nusa Cendana University, Penfui, Kupang, 85228, Indonesia \\ ${ }^{2}$ Faculty of Public Health, Airlangga University, Mulyorejo, Surabaya, 60115, Indonesia \\ ${ }^{3}$ Faculty of Medicine, Sebelas Maret University, Kentingan, Surakarta, 57126, Indonesia
}

\section{A R T I C L E I N F O}

IAKMI IPHJI use only:

Received date : 3 April 2020

Revised date : 23 April 2020

Accepted date : 25 May 2020

Keywords:

Knowledge

Stigma

Support

Religious Leader

\begin{abstract}
A B S T R A C T
Indonesia is ranked the third country with the fastest growth rate of HIV cases in Asia Pacific. HIV cases in Indonesia are mostly found in housewives. Therefore, religious leaders are involved to participate in addressing HIV issue in the community. Religious leader (RL) is one of the figures frequently visited by PLHIV in Kupang. This study aims to find out RLs' knowledge, stigma and support for PLHIV. This study is a quantitative descriptive study. The population of the study is RLs who have the gift of healing the sick in Kupang. The number of the sample is 51 . This study used questionnaire as research instrument. Data were analyzed descriptively and presented in a frequency table. 45 (85.2\%) RLs had poor knowledge, 46 (96.2\%) RLs had stigma against PLHIV and $44(86.3 \%)$ RLs provided support for PLHIV. It is necessary to improve RLs knowledge and eliminate stigma against PLHIV so that RLs can provide information and support for PLHIV treatment.
\end{abstract}

(c) 2020 IAKMI Indonesian Public Health Journal. All rights reserved

\section{INTRODUCTION ${ }^{*}$}

Indonesia is one of the 20 countries with the highest HIV cases in the world. In 2018, cases of HIV and AIDS in the world reached 37.9 million. In addition, Indonesia has the fastest growth rate of HIV cases in the Asia Pacific after India and China. On average, 46.000 new cases are found in Indonesia every year [1]. In 2018, 441.347 cases of HIV and AIDS were reported [2]. The number of cases of HIV and AIDS in East Nusa Tenggara (ENT) in 2018 reached 6.192 with 887 new cases. Kupang is the district/city with the most HIV cases in ENT. Based on occupation, the distribution of HIV and AIDS cases was found the most in housewives. Likewise, there has also been an increase in HIV cases in children under the age of four [3]. These facts show that HIV and AIDS has become an issue at the household level. Therefore, the empowerment

\footnotetext{
* Corresponding author.

E-mail address: imelda.manurung@staf.undana.ac.id
}

of all levels of society to actively participate in efforts to treat HIV and AIDS must continue to be driven. Community-based HIV treatment puts the community as agents to achieve the expected goals. The results achieved are more effective because they can overcome overall social and structural barriers to health and human rights [4]. Community mobilization for HIV and AIDS treatment is powerful because leaders, agents and targets are in the community [5]. The influence of community leaders is very effective in delivering the message of HIV and AIDS and supporting good behavior change [6]. Religious leader is among influential leaders in society. Religious leader $(R L)$ is proven to be able to deliver messages and support good behavior change in the community to treat HIV and AIDS [7]. Religious leader's support to campaign for the elimination of stigma in people living with HIV is obeyed by the community [8]. This is because RL has the power and charisma to influence followers' mind and behavior [9]. 
Many people in East Nusa Tenggara (ENT) rely on RL's ability to heal the sick. They believe that RL has a gift from God to cure all kinds of diseases including AIDS [10]. The community is very obedient to RL's commands for recovery [11].

The results of preliminary survey showed that that most of the times, advice given by RLS are contrary to the advice given by medical personnel. The advice given by RL to PLHIV include: taking medicine is unnecessary because the disease has been cured by God. The stigma against PLHIV is one of the factors that influence the success of HIV and AIDS treatment [12]. Stigma may reduce PLHIV's quality of life in an attempt to maintain their health. In addition, stigma also affects social interaction in the community [13]. RL as a respected person in the community has the potential to facilitate the elimination of stigma in PLHIV. Therefore, this study aims to examine RL's knowledge, stigma and support for PLHIV.

\section{METHOD}

\section{This}

study

a quantitative descriptive study

is a quantitative descriptive study [14]. The population and samples of the study are 51 religious leaders representing each village in Kupang. The RL criterion in this study is recognized by the community as having the gift of healing from God. The variables of the study are knowledge, stigma and support. Questionnaire was used as the instrument of the study. The knowledge variable consists of 6 statements to be responded with True or False. The stigma and support variables consist of 4 statements each to be responded with Yes or No. Score 1 is given for each correct respond, otherwise score 0 is given. For the knowledge and support variables, a total score of more than 70 percent is classified as good. Score less than 70 percent is classified as poor. As for the stigma variable, a total score of more than 70 is classified as low and less than 70 is classified as high. Data were analyzed descriptively and presented in a frequency table.

\section{RESULTS AND DISCUSSION}

The results showed that most RL are female aged over 40 years old.
Based on table 1 , in the knowledge variable, the most correctly responded statement was 'HIV is a preventable disease', responded correctly by $35(68.6 \%)$ RLs.

Table 1. Description of Characteristic, Knowledge, Stigma and Support for PLHIV

\begin{tabular}{|c|c|c|}
\hline Variable & Frequency & $\begin{array}{l}\text { Percent } \\
(\%)\end{array}$ \\
\hline \multicolumn{3}{|l|}{ Characteristics } \\
\hline$:<40$ tahun & 12 & 23.5 \\
\hline$\geq 40$ tahun & 39 & 76.5 \\
\hline \multirow[t]{2}{*}{ Sex } & 20 & 39.2 \\
\hline & 31 & 60.8 \\
\hline \multirow{2}{*}{$\begin{aligned} \text { Education : } & \leq \text { Junior High School } \\
& \geq \text { Senior High School }\end{aligned}$} & 11 & 21.6 \\
\hline & 40 & 78.4 \\
\hline \multicolumn{3}{|l|}{$\begin{array}{l}\text { Knowledge (RL who responded } \\
\text { correctly): }\end{array}$} \\
\hline $\begin{array}{l}\text { a. Someone with HIV can be } \\
\text { discovered just by looking at }\end{array}$ & 15 & 29.4 \\
\hline $\begin{array}{l}\text { b. There is no treatment to } \\
\text { cure HIV }\end{array}$ & 21 & 41.2 \\
\hline $\begin{array}{l}\text { c. Sharing food can transmit } \\
\text { HIV }\end{array}$ & 9 & 17.6 \\
\hline $\begin{array}{l}\text { d. Someone who is infected } \\
\text { with HIV will easily transmit } \\
\text { it to their sex partners }\end{array}$ & 5 & 9.8 \\
\hline $\begin{array}{l}\text { e. HIV is only transmittable to } \\
\text { people who have had sex } \\
\text { with female sex workers }\end{array}$ & 7 & 13.7 \\
\hline \multirow{2}{*}{$\begin{array}{l}\text { f. HIV is a preventable disease } \\
\text { Stigma : (RL who gave stigma) }\end{array}$} & 35 & 68.6 \\
\hline & & \\
\hline \multirow{4}{*}{$\begin{array}{l}\text { a. AIDS is a disease of } \\
\text { punishment } \\
\text { b. PLHIV must be ostracized } \\
\text { c. AIDS is a disease caused by } \\
\text { immoral behavior. } \\
\text { d. PLHIV cannot go to school }\end{array}$} & 45 & 88.2 \\
\hline & 31 & 60.8 \\
\hline & 47 & 92.2 \\
\hline & 35 & 68.6 \\
\hline Variable & Frequency & $\begin{array}{c}\text { Percent } \\
(\%)\end{array}$ \\
\hline \multicolumn{3}{|l|}{$\begin{array}{l}\text { Support (RL who } \quad \text { provided } \\
\text { support): }\end{array}$} \\
\hline \multicolumn{3}{|l|}{ a. Praying for the PLHIV to heal } \\
\hline \multicolumn{3}{|l|}{$\begin{array}{l}\text { b. Asking PLHIV to } \\
\text { medical treatment }\end{array}$} \\
\hline $\begin{array}{l}\text { c. Offering non-medical } \\
\text { therapy }\end{array}$ & 44 & 86.3 \\
\hline \multicolumn{3}{|l|}{$\begin{array}{l}\text { d. Protecting PLHIV from } \\
\text { stigma from the community }\end{array}$} \\
\hline Knowledge (Poor) & 45 & 88.2 \\
\hline Stigma & 46 & 90.2 \\
\hline Support & 44 & 88.3 \\
\hline
\end{tabular}

The least correctly responded statement was 'Someone who is infected with HIV will easily transmit it to their sex partners'. Only 5 $(9.8 \%)$ RLs responded correctly to this statement. $47(92.2 \%)$ RLs gave the stigma of 
'AIDS is a disease caused by immoral behavior'. Among the statements regarding stigma, 'PLHIV must be ostracized' was the least correctly responded stigma by $31(60.8 \%)$ RLs. The most support provided by RLs was praying for the PLHIV to heal, provided by 47 (92.1\%) RLs, followed by offering non-medical therapy, provided by $44(86.2 \%)$ RLs. The results of descriptive analysis of knowledge variable showed that the number of $\mathrm{RL}$ who had a good knowledge is $6(11.8 \%)$. The number of RL who gave low stigma to PLHIV is 5 (9.8\%). Almost all RLs 44 (88.3\%) provided high support for PLHIV.

HIV and AIDS treatment by empowering religious leader has been proven to be effective based on many studies in various parts of the world [15]. The results of this study showed that most RLs had a poor knowledge. This may be because RLs had never obtained information about HIV and AIDS [16]. One has a poor knowledge due to their low awareness to access information and the lack of exposure to information from the government to campaign on HIV and AIDS treatment [17]. Knowledge is essential in supporting behavior formation. The better a person's knowledge, the better their behavior to support HIV prevention [18]. Study on teenagers in Yogyakarta shows that knowledge is related to HIV prevention behavior [19]. If RLs had a poor knowledge about HIV, the behavior to carry out HIV treatment would be hard to realize. Stigma is the act of giving a social label that aims to exclude someone with a bad image. Stigma results in acts of discrimination that ignore one's basic rights and dignity [12]. Most RLs gave stigma to PLHIV. The stigma given includes HIV is a disease of punishment and a result of immoral behavior. In addition, RLs also gave the stigma that PLHIV must be ostracized. Giving stigma to PLHIV was affected by lack of knowledge. RLs did not know how HIV was transmitted so that they gave a bad image on PLHIV. A study conducted in Nigeria to nursing students shows that good knowledge reduces the stigma to people living with HIV [20]. The results of this study indicated that although RLS had poor knowledge and high stigma, most RLs provided a great support for PLHIV. This is because RLs can accept anyone and have the motivation to serve everyone. RLs love everyone who needs help. They are even ready to provide support for PLHIV who experience stigma from the community. The study conducted in South Africa shows that RL is able to motivate congregations to take HIV tests [21]. Church leaders and congregational groups have the strength in the form of love, attention, and mental recovery by using their faith to support PLHIV . RL is trusted as having high integrity and strong faith [22]. RL also has the power to influence and mobilize people for an ultimate goal, namely to repent, to make peace, and to make a better life [23].

\section{CONCLUSION}

This study concluded that although RLs had a poor knowledge and high stigma for PLHIV, they provided a great support for PLHIV. Therefore, efforts to improve knowledge and eliminate stigma are necessary so that RLs can provide support that is in line with treatment for PLHIV.

\section{ACKNOWLEDGMENT}

The authors gratefully thank all the religious leaders who have been involved in this research, GMIT Church that assisted in providing data of praying fellowship, AIDS Commission of ENT Province that took the time to complete the survey.

\section{REFERENCES}

[1] UNAIDS. Global factsheets 2018. [cited 20 Januari 2020]. Available from: https://aidsinfo.unaids.org

[2] Kementrian Kesehatan RI. Profil Kesehatan Indonesia 2018. Jakarta: Kemenkes RI; 2019.

[3] Dinas Kesehatan Provinsi NTT. Profil Kesehatan Provinsi Nusa Tenggara Timur 2018. Kupang: Dinkes Provinsi NTT; 2019.

[4] Kerrigan D, Kennedy CE, Morgan-Thomas $\mathrm{R}$, Reza-Paul S, Mwangi P, Win KT, McFall A, Fonner VA, Butler J. A community empowerment approach to the HIV response among sex workers: effectiveness, challenges, and considerations for implementation and 
scale-up. The Lancet. 2015 Jan 10;385(9963):172-85.

[5] Wirtz, A. L., Pretorius, C., Beyrer, C., Baral, S., Decker, M. R., Sherman, S. G., ... \& Semini, I. Epidemic impacts of a community empowerment intervention for HIV prevention among female sex workers in generalized and concentrated epidemics. PLoS One, (2014) 9(2).

[6] UNAIDS. Community Mobilization. [cited 20 Januari 2018]. Available from: https://www.unaids.org/en/topic/commu nity

[7] Asekun-Olarinmoye, I. O., AsekunOlarinmoye, E. O., Fatiregun, A., \& Fawole, O. I. Perceptions and activities of religious leaders on the prevention of HIV/AIDS and care of people living with the HIV infection in Ibadan, Nigeria. HIV/AIDS (Auckland, NZ), (2013) 5, 121.

[8] Bradley, E. L., Sutton, M. Y., Cooks, E., Washington-Ball, B., Gaul, Z., Gaskins, S., \& Payne-Foster, P. Developing FAITHH: Methods to develop a faith-based HIV stigma-reduction intervention in the rural south. Health promotion practice, (2018) 19(5), 730-740.

[9] Mubasher, U. E. F., Salman, Y., Irfan, S., \& Jabeen, N. Spiritual Leadership in Organizational Context: A Research Gap in South Asia. South Asian Studies (1026678X), 32(1) (2017).

[10] Manurung, I. F., Probandari, A., Wahyuni, C. U., \& Nugroho, H. S. W. The Role of Religious Leader Support on Voluntary Counseling and Testing (VCT) Behavior of Individuals at Risk of HIV/AIDS in Kupang City, Indonesia. Indian Journal of Forensic Medicine \& Toxicology, (2019) 13(4), 1527-1532.

[11] Manurung, I. F., Ndun, H. J., Ruliati, L. P., Baun, A. H., Lele, Y. K., \& Wahyuni, C. (2020, February). Knowledge and Practice of Informal Religious Leaders in Referring Tuberculosis Suspects to Visit Public Health Center. In 4th International Symposium on Health Research (ISHR 2019) (pp. 425-428). Atlantis Press.

[12] Kemenkes RI. Buku Pedoman Penghapusan Stigma dan Diskriminasi Bagi Pengelola Program, Petugas Layanan Kesehatan dan Kader. (2012) 1.
[13] Than, P. Q. T., Tran, B. X., Nguyen, C. T., Truong, N. T., Thai, T. P. T., Latkin, C. A., ... \& Ho, R. C. Stigma against patients with HIV/AIDS in the rapid expansion of antiretroviral treatment in large drug injection-driven HIV epidemics of Vietnam. Harm reduction journal, (2019) 16(1), 6.

[14] Nazir, M. Metode Penelitian. Bogor: Ghalia Indonesia (2013)

[15] Pichon, L. C., Griffith, D. M., Campbell, B., Allen, J. O., Williams, T. T., \& Addo, A. Y. Faith leaders' comfort implementing an HIV prevention curriculum in a faith setting. Journal of Health Care for the Poor and Underserved, (2012) 23(3), 1253-1265.

[16] Manurung, I. F., UW, C., \& Probandari, A. Effect of Health Literacy to the Empowered Servant of God in Supporting Individuals at Risk of HIV and AIDS to Follow VCT. International Journal of Sciences: Basic and Applied Research, (2016) 26(1), 231-236.

[17] Haroun, D., El Saleh, O., Wood, L., Mechli, R., Al Marzouqi, N., \& Anouti, S. Assessing knowledge of, and attitudes to, HIV/AIDS among university students in the United Arab Emirates. PloS one, (2016) 11(2).

[18] Choudhary, H. A., Ali, R. A., \& Altaf, S. Knowledge, behaviour and attitudes regarding HIV/AIDS among undergraduate students in an Irish university. International Journal of Surgery and Medicine, (2015) 1(2), 5866.

[19] Purnamaningrum, Y. E., Nugrahawati, R. E. P. C., Hernayanti, M. R., \& Vajee, A. Factors Related to Adolescent Behavior towards HIV/AIDS Prevention. Kesmas: National Public Health Journal, (2019) 13(4), 195-201.

[20] Farotimi, A. A., Nwozichi, C. U., \& Ojediran, T. D. Knowledge, attitude, and practice of HIV/AIDS-related stigma and discrimination reduction among nursing students in southwest Nigeria. Iranian journal of nursing and midwifery research, (2015) 20(6), 705.

[21] Jobson, G., Khoza, S., Mbeng, R., Befula, N., Struthers, H. E., Kerongo, G., \& Peters, R. P.. Bridging the Gap: Reaching 
Men for HIV Testing Through Religious Congregations in South Africa. Journal of acquired immune deficiency syndromes (1999), (2019) 81(5), e160.

[22] Abara, W., Coleman, J. D., Fairchild, A., Gaddist, B., \& White, J. A faith-based community partnership to address HIV/AIDS in the Southern United States: Implementation, challenges, and lessons learned. Journal of religion and health, (2015) 54(1), 122-133.

[23] Ramírez-Johnson, J., Díaz, H. L., Feldman, J. B., \& Ramírez-Jorge, J. Empowering Latino church leaders to deal with the HIV-AIDS crisis: a strengthsoriented service model. Journal of religion and health, (2013) 52(2), 570-588. 
IAKMI Public Health Journal Indonesia

Volume 1 No 1 June 2020

Website : http://jurnal.iakmi.id/index.php/IPHJI

e-ISSN : 2722-550X 